\title{
The Effect of Biofertilizer and Salinity Stress on Amaranthus tricolor L. Growth and Total Leaf Chlorophyll Content
}

\author{
Dwi Umi Siswanti ${ }^{1 *}$, and Nadhifa Athaya Khairunnisa ${ }^{2}$ \\ ${ }^{1}$ Faculty of Biology, Universitas Gadjah Mada, Jl. Teknika Sel., Yogyakarta Special Region 55281, \\ Indonesia \\ ${ }^{2}$ Faculty of Biology, Universitas Gadjah Mada, Jl. Teknika Sel., Yogyakarta Special Region 55281, \\ Indonesia
}

\begin{abstract}
Amaranth is one of the most consumed vegetables in Indonesia. Meanwhile, the productions of plants are affected by productivity and environmental factors such as abiotic stresses. One of these is salinity, which affects plant growth and becomes an issue in the agricultural sector. Moreover, biofertilizer contains microbial elements that are necessary for plant growth and play an important role in the nutrient cycle of the soil. Therefore, this study aims to analyze the effect of biofertilizer combined with $\mathrm{NaCl}$ on Amaranthus tricolor $\mathrm{L}$. growth. The biofertilizer doses used were $10 \mathrm{~L} / \mathrm{ha}, 20 \mathrm{~L} / \mathrm{ha}$, and $30 \mathrm{~L} / \mathrm{ha}$, each combined with manure fertilizer and $2500 \mathrm{ppm}, 5000 \mathrm{ppm}, 7500 \mathrm{ppm}$, and $10.000 \mathrm{ppm}$ of $\mathrm{NaCl}$. The parameters were measured using quantitative methods while a UV-vis spectrophotometer was used for the chlorophyll content. Meanwhile, the results were analyzed using the one-way ANOVA method at a 95\% of confidence level. This analysis showed that the highest amaranth growth was found in $0 \mathrm{l} / \mathrm{ha}$ of biofertilizer combined with $7500 \mathrm{ppm} \mathrm{NaCl}$ treatment, a number of leaves in $10 \mathrm{l} / \mathrm{ha}$ biofertilizer, and $2500 \mathrm{ppm} \mathrm{NaCl}$, and chlorophyll content in $30 \mathrm{l} / \mathrm{ha}$ biofertilizer. Based on the results, biofertilizer had an insignificant effect on plant growth while fertilizer had, while the most appropriate biofertilizer dose for chlorophyll content was 30 1/ha.
\end{abstract}

Keywords: Amaranthus, Biofertilizer, Chlorophyll Content, Productivity, Saline Condition.

\section{Introduction}

Amaranthus is a widely spread crops in the tropical and subtropical regions such as southeast Asia and consist of 70 species in a various type, such as cosmopolitan weed or cultivated plant. Meanwhile, Amaranthus tricolor is popular in Southeast Asia as a consumed vegetable and is considered the most economically important crop. However, the demand for this plant varied with the effort to improve its nutritional value and productivity. The Amaranthus

* Corresponding author: dwiumi@ugm.ac.id 
tricolor species is a widely cultivated Amaranth that is used as a vegetable because of its protein content $[2,5]$.

Generally, the soil has insufficient nutrients for plant growth, therefore, providing fertilizer is among the efforts of farmers to increase soil fertility for amaranth plant production. However, the use of fertilizers in large quantities harms the environment. With an increase in the human population, the demand for food production increases which is a problem for the agricultural sector. Based on previous studies, this problem is solved by applying the role of microbes. Moreover, biofertilizer is a material that contains living microorganisms that the promotes growth and production of the plant by facilitating the available nutrients in the soil. These products play a role in increasing crop production through direct or indirect mechanisms. Therefore, the use of biofertilizer products is essential because it minimizes the negative impact on the environment due to its environmentally friendly nature $[3,4]$.

Salinity or hyper ionic stress is an accumulation of salt concentrations in the soil. Meanwhile, the salt content that affects plant growth and as a stress factor in plants includes $\mathrm{Na}^{+}$and $\mathrm{Cl}^{-}$ions. Therefore, soil salinity becomes an abiotic stress factor for plants due to the presence of $\mathrm{Na}^{+}$ions and $\mathrm{Cl}^{-}$in plant cells which leads to ion imbalance and physiological changes, causing irregular and excessive water absorption. The high concentration of $\mathrm{Na}^{+}$ ions inhibits the absorption of $\mathrm{K}^{+}$ions which play a role in plant growth and development and affects plant productivity [6].

High salt concentration in the root part is caused by human activities in the agricultural field such as irrigation or occurs naturally. The presence of salt content in the soil inhibits plant growth and productivity. Furthermore, salt accumulation causes the disturbance of metabolism and affects important phases in plant growth such as germination, seed growth, vegetative phase, flowering, and fruit formation. Also, salinity causes osmotic stress in plants, disruption of ion transport, and creates a toxic environment due to the accumulation of sodium and chloride on cell activity [7].

\section{Materials and Methods}

\subsection{Materials}

Materials used include basic manure fertilizer, cow's urine, bacteria starter consist of Bacillus sp., Saccharomyces sp., Streptomyces sp., Azospirillum sp., Pseudomonas sp., Azotobacter sp., Rhizobium sp., IAA producing bacteria. $\mathrm{NaCl}$ with variation concentration of $2500 \mathrm{ppm}, 5000 \mathrm{ppm}, 7500 \mathrm{ppm}$, and $10.000 \mathrm{ppm}$, amylum indicator $1 \%$, iodine indicator $0.01 \mathrm{~N}$, Erlenmeyer flask, semi-analytic scale, and UV-vis spectrophotometer.

\subsection{Methods}

\subsubsection{Study Area}

The study was carried out at the greenhouse of the Faculty of Biology, Universitas Gadjah Mada which is located in the Special Region of Yogyakarta. 


\subsubsection{Procedures}

The study was conducted at the Faculty of Biology, Universitas Gadjah Mada from September to November 2020. The study of chlorophyll was conducted in the Plant Physiology Laboratory, Universitas Gadjah Mada. Meanwhile, this study was carried out by administering a biofertilizer treatment based on the formula method used in the previous study. The biofertilizer used was made with the mixture of cow's urine and a starter in form of a microbial in the ratio of 49:1 [1]. Furthermore, the dose of 10 1/ha, 20 1/ha, and $301 / \mathrm{ha}$ of biofertilizer was used. For the salinity stress, $\mathrm{NaCl}$ was used in the 4 concentration variation of $2500 \mathrm{ppm}, 5000,7500 \mathrm{ppm}$, and $10000 \mathrm{ppm}$ respectively. Each planting medium was combined with manure as the basic fertilizer and was mixed with basic manure in the ratio of 1:1:1. Meanwhile, the parameters that were measured include plant height and the number of leaves, while chlorophyll a, chlorophyll b, and total chlorophyll content were measured using 645 and $663 \mathrm{~nm}$ wavelength of UV-vis spectrophotometer.

\subsubsection{Data Analysis}

The data were analyzed using SPSS 20 with one-way ANOVA and the RCBD method at a $95 \%$ of confidence level $(\alpha=0.05 \%)$. The results were proceed using the Duncan Multiple Range Test (DMRT).

\section{Results and Discussion}

\subsection{Results}

Based on the study, the data obtained as shown below include plant height (figure 1), number of leaves (figure 2), and chlorophyll content (figure 3).

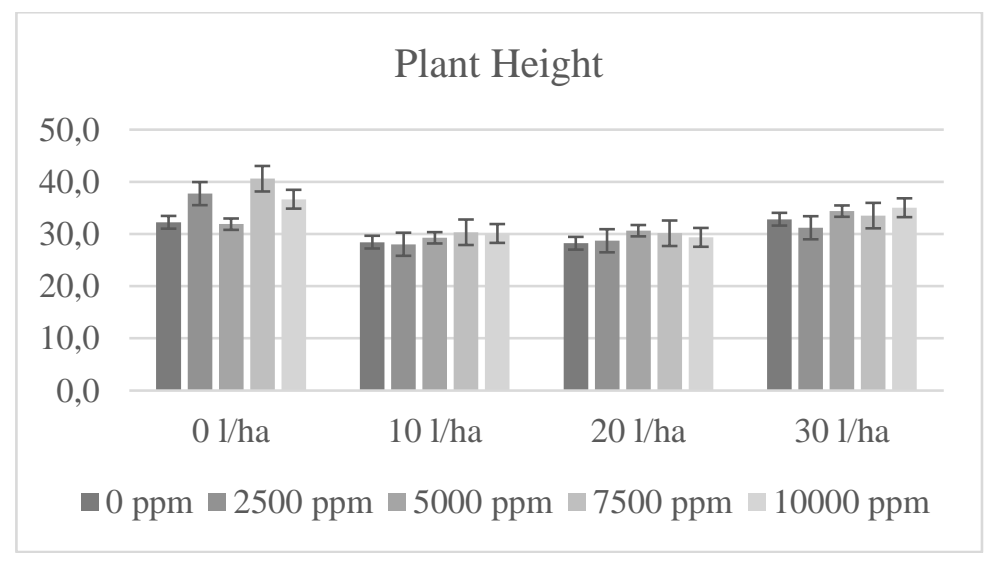

Figure 1. The effect of biofertilizer and salinity stress on the height of Amaranthus tricolor. 


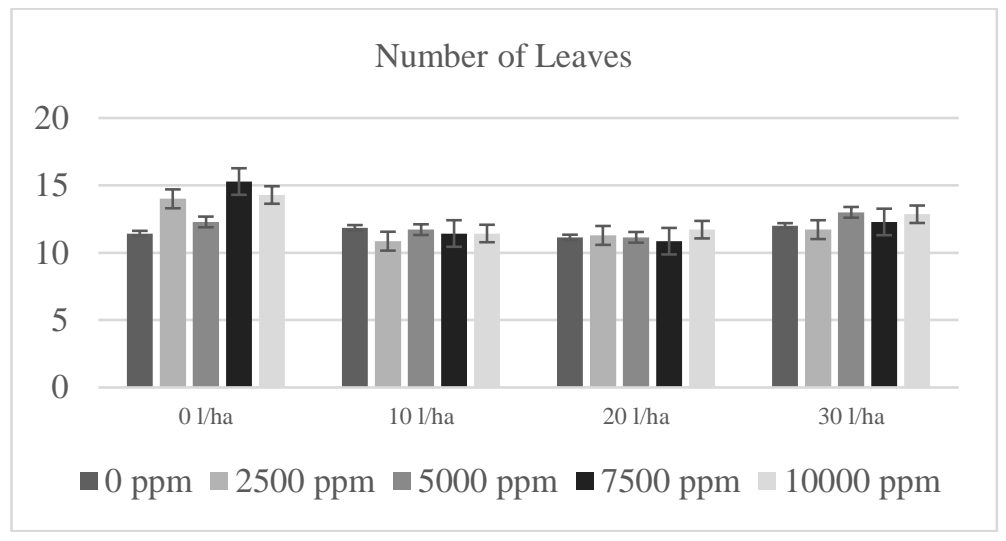

Figure 2. The effect of biofertilizer and salinity stress on the number of leaves of Amaranthus tricolor.

Based on figure 2, the data of plant height and number of leaves were obtained. The results showed that the treatment with $7500 \mathrm{ppm}$ and 0 1/ha biofertilizer indicated the highest growth and productivity compared to another treatment, while the lowest plant height was shown by the results of $2500 \mathrm{ppm}$ of $\mathrm{NaCl}$ and $10 \mathrm{l} / \mathrm{ha}$ biofertilizer. For the number of leaves of the plant, the results showed that the best productivity is achieved by the combination of $7500 \mathrm{ppm}$ of $\mathrm{NaCl}$ and $0 \mathrm{l} / \mathrm{ha}$ of biofertilizer. Meanwhile, the lowest productivity showed that the number of leaves was in the treatment of 10 1/ha biofertilizer and $2500 \mathrm{ppm} \mathrm{NaCl}$ concentrations.

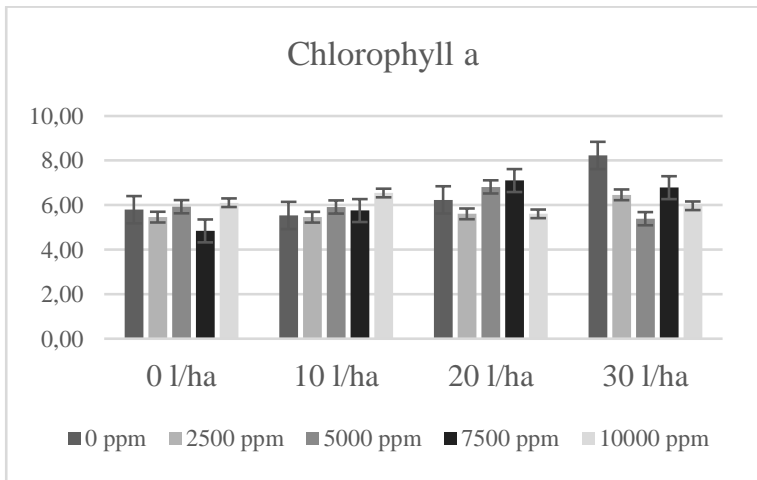

(a)

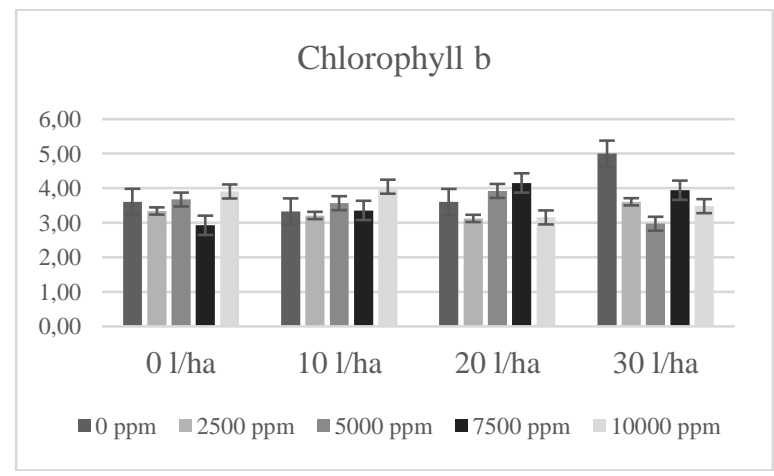

(b)

Figure 3. The effect of biofertilizer and salinity stress on; (a) chlorophyll a and (b) chlorophyll b. 


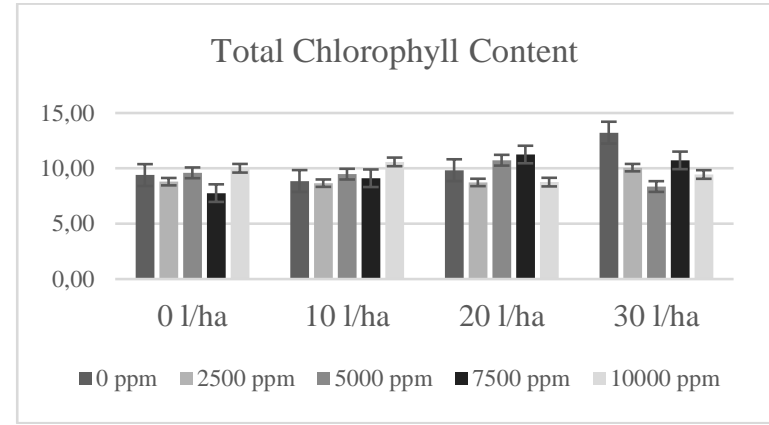

(c)

Figure 4. The effect of biofertilizer and salinity stress on total chlorophyll.

Based on figure 3 , the data of chlorophyll a, chlorophyll $b$, and total chlorophyll were obtained. The results showed that the treatment with $0 \mathrm{ppm}$ and $30 \mathrm{l} / \mathrm{ha}$ biofertilizer indicated the highest chlorophyll content compared to another treatment while the lowest chlorophyll content was shown by the results of $0 \mathrm{ppm}$ of $\mathrm{NaCl}$ and $01 /$ ha biofertilizer (control treatment).

Table 1. The effect of biofertilizer on the growth of Amaranthus tricolor L.

\begin{tabular}{|c|c|c|}
\hline \multirow[b]{2}{*}{ Treatments } & \multicolumn{2}{|c|}{ Parameters } \\
\hline & Plant Height & $\begin{array}{c}\text { Number of } \\
\text { Leaves }\end{array}$ \\
\hline $0 \mathrm{ppm} \mathrm{NaCl}+01 /$ ha biofertilizer & $32.2429 \pm 7.14^{\text {abcd }}$ & $11 \pm 1.1^{\mathrm{ab}}$ \\
\hline $2500 \mathrm{ppm} \mathrm{NaCl}+0$ 1/ha biofertilizer & $37.7429 \pm 4.12^{\mathrm{de}}$ & $14 \pm 2.1^{\text {cde }}$ \\
\hline $5000 \mathrm{ppm} \mathrm{NaCl}+0$ 1/ha biofertilizer & $31.8857 \pm 6.5^{\mathrm{abcd}}$ & $12 \pm 1.3^{\mathrm{abc}}$ \\
\hline $7500 \mathrm{ppm} \mathrm{NaCl}+0$ 1/ha biofertilizer & $40.5929 \pm 5.08^{\mathrm{e}}$ & $15 \pm 2.3^{\mathrm{e}}$ \\
\hline $10000 \mathrm{ppm} \mathrm{NaCl}+0$ 1/ha biofertilizer & $36.6643 \pm 5.81^{\text {cde }}$ & $14 \pm 3.03^{\mathrm{de}}$ \\
\hline $0 \mathrm{ppm} \mathrm{NaCl}+10$ l/ha biofertilizer & $28.4429 \pm 5.01^{\mathrm{a}}$ & $12 \pm 2.34^{\mathrm{ab}}$ \\
\hline $2500 \mathrm{ppm} \mathrm{NaCl}+10$ 1/ha biofertilizer & $28.0357 \pm 4.03^{\mathrm{a}}$ & $11 \pm 0.69^{a}$ \\
\hline $5000 \mathrm{ppm} \mathrm{NaCl}+10$ 1/ha biofertilizer & $29.2714 \pm 2.80^{\mathrm{ab}}$ & $12 \pm 0.76^{\mathrm{ab}}$ \\
\hline $7500 \mathrm{ppm} \mathrm{NaCl}+10$ 1/ha biofertilizer & $30.3357 \pm 4.62^{\mathrm{ab}}$ & $11 \pm 0.98^{\mathrm{ab}}$ \\
\hline $\begin{array}{l}10000 \mathrm{ppm} \mathrm{NaCl}+10 \text { 1/ha } \\
\text { biofertilizer }\end{array}$ & $30.1071 \pm 3.80^{\mathrm{ab}}$ & $11 \pm 1.27^{\mathrm{ab}}$ \\
\hline $0 \mathrm{ppm} \mathrm{NaCl}+20$ l/ha biofertilizer & $28.2286 \pm 1.85^{\mathrm{a}}$ & $11 \pm 1.06^{\mathrm{ab}}$ \\
\hline $2500 \mathrm{ppm} \mathrm{NaCl}+20$ 1/ha biofertilizer & $28.7071 \pm 3.69^{\mathrm{a}}$ & $11 \pm 1.38^{\mathrm{ab}}$ \\
\hline $5000 \mathrm{ppm} \mathrm{NaCl}+201 /$ ha biofertilizer & $30.6357 \pm 4.28 \mathrm{abc}$ & $11 \pm 0.90^{\mathrm{ab}}$ \\
\hline $7500 \mathrm{ppm} \mathrm{NaCl}+20$ 1/ha biofertilizer & $30.1429 \pm 2.07^{\mathrm{ab}}$ & $11 \pm 0.90^{\mathrm{a}}$ \\
\hline $\begin{array}{l}10000 \mathrm{ppm} \\
\text { biofertilizer }\end{array}$ & $29.3571 \pm 3.39^{\mathrm{ab}}$ & $12 \pm 1.25^{\mathrm{ab}}$ \\
\hline $0 \mathrm{ppm} \mathrm{NaCl}+30$ l/ha biofertilizer & $32.8357 \pm 6.08^{\mathrm{abcd}}$ & $12 \pm 1.41^{\mathrm{ab}}$ \\
\hline
\end{tabular}




\begin{tabular}{lll}
$2500 \mathrm{ppm} \mathrm{NaCl}+30$ 1/ha biofertilizer & $31.2 \pm 4.94^{\mathrm{abc}}$ & $12 \pm 0.95^{\mathrm{ab}}$ \\
$5000 \mathrm{ppm} \mathrm{NaCl}+30$ 1/ha biofertilizer & $34.3857 \pm 4.71^{\mathrm{abcd}}$ & $13 \pm 1.15^{\mathrm{bcd}}$ \\
$\begin{array}{l}7500 \mathrm{ppm} \mathrm{NaCl}+30 \text { 1/ha biofertilizer } \\
10000 \mathrm{ppm} \mathrm{NaCl}+30 \mathrm{~N} \text { 1/ha } \\
\text { biofertilizer }\end{array}$ & $35.5286 \pm 7.07^{\mathrm{abcd}}$ & $12 \pm 1.89^{\mathrm{abc}}$ \\
\hline
\end{tabular}

Based on table 1, the ANOVA analyses provide the data of plant height and number of leaves. For the plant height, the results showed that the treatment with $7500 \mathrm{ppm}$ and $0 \mathrm{l} / \mathrm{ha}$ biofertilizer is significantly different compared to the $10 \mathrm{l} / \mathrm{ha}, 20 \mathrm{l} / \mathrm{ha}$, and $30 \mathrm{l} / \mathrm{ha}$ dose of biofertilizer. Meanwhile, for the number of leaves, the treatment with $7500 \mathrm{ppm}$ and $0 \mathrm{l} / \mathrm{ha}$ biofertilizer is significantly different compared to the $10 \mathrm{l} / \mathrm{ha}, 20 \mathrm{l} / \mathrm{ha}$, and $30 \mathrm{l} / \mathrm{ha}$ doses of biofertilizer.

Based on table 2, the ANOVA analysis provided the data of chlorophyll content. For the chlorophyll, the result of the combination of $0 \mathrm{ppm} \mathrm{NaCl}$ and 30 1/ha biofertilizer was significantly different compared to the other treatments. However, For chlorophyll b, there were no significantly different treatments that affected the chlorophyll content. For the total chlorophyll content, there were no significantly different treatments affecting the chlorophyll content.

\subsection{Discussion}

Based on this study, the data of plant height and number of leaves, and chlorophyll content were obtained. The results showed that the treatment with $7500 \mathrm{ppm}$ and $0 \mathrm{l} / \mathrm{ha}$ biofertilizer indicated the highest growth and productivity compared to another treatment, while the lowest plant height was shown by the results of $2500 \mathrm{ppm}$ of $\mathrm{NaCl}$, and $10 \mathrm{l} / \mathrm{ha}$ biofertilizer. For the number of leaves of the plant, the result showed that the best productivity was provided by the combination of $7500 \mathrm{ppm}$ of $\mathrm{NaCl}$, in $0 \mathrm{l} / \mathrm{ha}$ of biofertilizer, while the lowest productivity showed by the number of leaves was in the treatment of $10 \mathrm{l} / \mathrm{ha}$ biofertilizer and $2500 \mathrm{ppm} \mathrm{NaCl}$ concentration. In high salinity concentration, the plant provided the highest growth and number of leaves without applying the biofertilizer. This is because the planting medium is using manure fertilizer which provides a direct nutrient uptake for the plant growth. Meanwhile, $7500 \mathrm{ppm}$ is the salinity tolerance for the plant which forced them to survive and grow taller compared to others. In the $10.000 \mathrm{ppm}$, the salinity stress was relatively high for the plant, causing a reduction in its productivity.

The data of chlorophyll a, chlorophyll $b$, and total chlorophyll showed that the treatment with $0 \mathrm{ppm}$ and $30 \mathrm{l} / \mathrm{ha}$ biofertilizer indicated the highest chlorophyll content compared to another treatment, while the lowest chlorophyll content was shown by the results of $0 \mathrm{ppm}$ of $\mathrm{NaCl}$, and $01 /$ ha biofertilizer (control treatment). Meanwhile, the highest dose of biofertilizer provides more nutrients for the plant through its microbial activity, therefore, the productivity and the required nutrients for photosynthesis were provided. 
Table 2. The effect of biofertilizer on the chlorophyll content of Amaranthus tricolor $\mathrm{L}$.

\begin{tabular}{|c|c|c|c|c|c|c|}
\hline \multirow{2}{*}{\multicolumn{4}{|c|}{ Treatments }} & \multicolumn{3}{|c|}{ Parameters } \\
\hline & & & & $\begin{array}{c}\text { Chlorophyll } \\
\mathrm{a}\end{array}$ & $\begin{array}{c}\text { Chlorophyll } \\
\text { b }\end{array}$ & $\begin{array}{c}\text { Total } \\
\text { Chlorophyll }\end{array}$ \\
\hline \multicolumn{4}{|c|}{$0 \mathrm{ppm} \mathrm{NaCl}+0$ 1/ha biofertilizer } & $5.79 \pm 1.13^{\mathrm{a}}$ & $3.60 \pm 0.66^{\mathrm{ab}}$ & $9.40 \pm 1.8^{\mathrm{a}}$ \\
\hline $\begin{array}{l}2500 \text { ppm } \\
\text { biofertilizer }\end{array}$ & $\mathrm{NaCl}$ & +0 & $1 / \mathrm{ha}$ & $5.46 \pm 0.31^{\mathrm{a}}$ & $3.34 \pm 0.62^{\mathrm{a}}$ & $8.80 \pm 0.37^{\mathrm{a}}$ \\
\hline $\begin{array}{l}5000 \text { ppm } \\
\text { biofertilizer }\end{array}$ & $\mathrm{NaCl}$ & +0 & $1 / \mathrm{ha}$ & $5.93 \pm 2.07^{\mathrm{a}}$ & $\begin{array}{l}3.672 \pm 1.29 \\
\text { ab }\end{array}$ & $9.60 \pm 3.37^{\mathrm{ab}}$ \\
\hline $\begin{array}{l}7500 \text { ppm } \\
\text { biofertilizer }\end{array}$ & $\mathrm{NaCl}$ & +0 & 1/ha & $4.84 \pm 1.54^{\mathrm{a}}$ & $2.93 \pm 1.10^{\mathrm{a}}$ & $7.76 \pm 2.64^{\mathrm{a}}$ \\
\hline $\begin{array}{l}10000 \mathrm{ppm} \\
\text { biofertilizer }\end{array}$ & $\mathrm{NaCl}$ & +0 & $1 / \mathrm{ha}$ & $6.11 \pm 0.91^{a b}$ & $3.90 \pm 0.35^{a b}$ & $10.00 \pm 1.23^{\mathrm{ab}}$ \\
\hline \multicolumn{4}{|c|}{$0 \mathrm{ppm} \mathrm{NaCl}+10$ 1/ha biofertilizer } & $5.53 \pm 0.55^{\mathrm{a}}$ & $3.33 \pm 46^{\mathrm{a}}$ & $8.86 \pm 0.98^{\mathrm{a}}$ \\
\hline $\begin{array}{l}2500 \mathrm{ppm} \\
\text { biofertilizer }\end{array}$ & $\mathrm{NaCl}$ & +10 & 1/ha & $5.45 \pm 0.61^{\mathrm{a}}$ & $3.21 \pm 0.26^{\mathrm{a}}$ & $8.66 \pm 0.87^{a}$ \\
\hline $\begin{array}{l}5000 \mathrm{ppm} \\
\text { biofertilizer }\end{array}$ & $\mathrm{NaCl}$ & +10 & $1 / \mathrm{ha}$ & $5.92 \pm 0.79^{a}$ & $3.57 \pm 0.43^{\mathrm{ab}}$ & $9.48 \pm 1.21^{\mathrm{a}}$ \\
\hline $\begin{array}{l}7500 \text { ppm } \\
\text { biofertilizer }\end{array}$ & $\mathrm{NaCl}$ & +10 & $1 /$ ha & $5.75 \pm 0.52^{\mathrm{a}}$ & $3.36 \pm 0.30^{\mathrm{a}}$ & $9.11 \pm 0.81^{\mathrm{a}}$ \\
\hline $\begin{array}{l}10000 \mathrm{ppm} \\
\text { biofertilizer }\end{array}$ & $\mathrm{NaCl}$ & +10 & 1/ha & $6.54 \pm 1.03^{a b}$ & $\begin{array}{l}4.044 \pm 0.73 \\
\text { ab }\end{array}$ & $10.59 \pm 1.75^{a b}$ \\
\hline \multicolumn{4}{|c|}{$0 \mathrm{ppm} \mathrm{NaCl}+20$ 1/ha biofertilizer } & $6.24 \pm 0.21^{\mathrm{ab}}$ & $3.60 \pm 0.14^{\mathrm{ab}}$ & $9.84 \pm 0.21^{\mathrm{ab}}$ \\
\hline $\begin{array}{l}2500 \mathrm{ppm} \\
\text { biofertilizer }\end{array}$ & $\mathrm{NaCl}$ & +20 & 1/ha & $5.61 \pm 0.35^{\mathrm{a}}$ & $3.13 \pm 0.44^{\mathrm{a}}$ & $8.73 \pm 0.68^{a}$ \\
\hline $\begin{array}{l}5000 \mathrm{ppm} \\
\text { biofertilizer }\end{array}$ & $\mathrm{NaCl}$ & +20 & $1 / \mathrm{ha}$ & $6.82 \pm 1.74^{a b}$ & $\begin{array}{l}3.921 \pm 0.92 \\
\text { ab }\end{array}$ & $10.74 \pm 2.66^{\mathrm{ab}}$ \\
\hline $\begin{array}{l}7500 \text { ppm } \\
\text { biofertilizer }\end{array}$ & $\mathrm{NaCl}$ & +20 & $1 / \mathrm{ha}$ & $7.10 \pm 1.46^{\mathrm{ab}}$ & $4.15 \pm 0.76^{\mathrm{ab}}$ & $11.25 \pm 2.23^{a b}$ \\
\hline $\begin{array}{l}10000 \mathrm{ppm} \\
\text { biofertilizer }\end{array}$ & $\mathrm{NaCl}$ & +20 & 1/ha & $5.61 \pm 0.88^{a}$ & $3.16 \pm 0.36^{\mathrm{a}}$ & $8.76 \pm 1.23^{\mathrm{a}}$ \\
\hline \multicolumn{4}{|c|}{$0 \mathrm{ppm} \mathrm{NaCl}+30$ 1/ha biofertilizer } & $8.23 \pm 1.31^{\mathrm{b}}$ & $5.00 \pm 1.36^{\mathrm{b}}$ & $13.23 \pm 2.68^{\mathrm{b}}$ \\
\hline $\begin{array}{l}2500 \mathrm{ppm} \\
\text { biofertilizer }\end{array}$ & $\mathrm{NaCl}$ & +30 & 1/ha & $6.46 \pm 0.88^{a b}$ & $3.61 \pm 0.63^{a b}$ & $10.06 \pm 1.51^{\mathrm{ab}}$ \\
\hline $\begin{array}{l}5000 \mathrm{ppm} \\
\text { biofertilizer }\end{array}$ & $\mathrm{NaCl}$ & +30 & $1 / \mathrm{ha}$ & $5.39 \pm 1.45^{\mathrm{a}}$ & $2.97 \pm 0.85^{\mathrm{a}}$ & $8.36 \pm 2.29^{\mathrm{a}}$ \\
\hline $\begin{array}{l}7500 \text { ppm } \\
\text { biofertilizer }\end{array}$ & $\mathrm{NaCl}$ & +30 & $1 / \mathrm{ha}$ & $6.78 \pm 1.28^{a b}$ & $3.94 \pm 0.87^{a b}$ & $10.72 \pm 2.16^{\mathrm{ab}}$ \\
\hline $\begin{array}{l}10000 \text { ppm } \\
\text { biofertilizer }\end{array}$ & $\mathrm{NaCl}$ & +30 & $1 / \mathrm{ha}$ & $3.97 \pm 1.78^{\mathrm{a}}$ & $3.48 \pm 1.19^{\mathrm{a}}$ & $3.45 \pm 2.97^{\mathrm{a}}$ \\
\hline
\end{tabular}




\section{Conclusion}

Based on the results, biofertilizer had an insignificant effect on plant growth while fertilizer had, while the most appropriate biofertilizer dose for chlorophyll content was $30 \mathrm{l} / \mathrm{ha}$.

The author is grateful for the Universitas Gadjah Mada RTA grant which supported the progress of this study.

\section{References}

1. D.U. Siswanti, Ind. J. of Com. En, 1, 62-78 (2015)

2. M. Jimoh, A.J. Afolayan, F. Lewu, S. A. J. of Bot, 115, 65-73 (2018)

3. M.L. Larramendy, S. Soloneski, Organic Fertilizers: From Basic Concepts to Applied Outcomes (InTech, Rijeka, 2016)

4. N.K. Arora, Plant Microbes Symbiosis: Applied Facets (Springer, New Delhi, 2015)

5. R. Andini, S. Yoshida, Y. Yoshida, R. Ohsawa, Genet. Resour. Crop. E 60, 2115-2128 (2013)

6. R.A. James, C. Blake, C.S. Byrt, R. Munns, J. Exp Bot, 62, 2939-2947 (2011)

7. V. Volkov, M.J. Beilby, J. Front. in Plant Sci. 8, 4, (2017) 